\title{
Techniques of Remote Sensing and GIS as Tools for Visualizing Impact of Climate Change-Induced Flood in the Southern African Region
}

\author{
Yaw A. Twumasi ${ }^{*}$, Edmund C. Merem¹, Tomas Ayala-Silva², Albert Osei ${ }^{3}$, Brilliant M. Petja ${ }^{4}$, \\ Kia Alexander ${ }^{5}$ \\ ${ }^{1}$ Department of Urban and Regional Planning, Jackson State University, Jackson, MS, USA \\ ${ }^{2}$ USDA-ARS Tropical Agriculture Research Station, Mayaguez, Puerto Rico \\ ${ }^{3}$ Department of Mathematics and Computer Sciences, Oakwood University, Huntsville, AL, USA \\ ${ }^{4}$ Water Research Commission (WRC) Private Bag X03, Gezina, South Africa \\ ${ }^{5}$ Texas Department of Agriculture (TDA), Dallas, TX, USA \\ Email: ^yaw.a.twumasi@jsums.edu,yaw.twumasi@gmail.com
}

How to cite this paper: Twumasi, Y.A., Merem, E.C., Ayala-Silva, T., Osei, A., Petja, B.M. and Alexander, K. (2017) Techniques of Remote Sensing and GIS as Tools for Visualizing Impact of Climate ChangeInduced Flood in the Southern African Region. American Journal of Climate Change, 6, 306-327.

https://doi.org/10.4236/ajcc.2017.62016

Received: March 1, 2017

Accepted: June 3, 2017

Published: June 6, 2017

Copyright $\odot 2017$ by authors and Scientific Research Publishing Inc. This work is licensed under the Creative Commons Attribution International License (CC BY 4.0).

http://creativecommons.org/licenses/by/4.0/

\begin{abstract}
Flooding is a major problem facing Southern African region. The region has been experiencing flood for the past two decades. This flood event has been exacerbated in recent years by global weather pattern known as La Niña which cools ocean waters in the equatorial Pacific and changes rainfall patterns across the world. This change in weather pattern has resulted in increased rainfall over Southern Africa causing flash floods resulting in extensive socioeconomic loses, casualties and environmental damage. This study employs remote sensing and geographical information systems (GIS) data to visualize the impact of climate change caused by flooding in the Southern African region in order to assist decision makers' plans for future occurrences. To achieve these objectives, the study used Digital Elevation Model (DEM), temporal Landsat Enhanced Thematic Mapper Plus (ETM+) and Moderate Resolution Imaging Spectroradiometer (MODIS) satellites data obtained from the United States Geological Survey (USGS) and NASA's Earth Observatory websites in order to show the spatial dimensions of the damage and the flooded area. Results of the study revealed notable damages to social and natural environments as well as flood risk zones and watercourses in the study area. The paper concludes by outlining policy recommendations in the form of the need for building drainage ditches on the flat plains identified in this study to accommodate flood flows, the design of a comprehensive Regional Emergency Information System (REIS) with support from the governments in the study area and the neighboring countries. Building such system, the paper con-
\end{abstract}


cludes could offer decision-makers access to the appropriate spatio-temporal data for monitoring climate change induced emergencies related to seasonal floods.

\section{Keywords}

Remote Sensing, Geographic Information Systems, Climate Change, Flooding, La Niña

\section{Introduction}

Floods caused by man-made and natural disasters are major environmental problems facing the world. In recent years, flooding associated with rainstorms has been largely attributed to climate change [1] [2] [3] [4]. In particular, areas adjacent to the coastal areas and inlands, close to watercourses, have seen a rise in flooding activities. The rate of occurrences of these flood events has increased globally over the last two decades with disastrous effects [5]. According to a chronology of flood events reported in NASA's Earth Observatory (EO) and Natural Hazards Magazine by Herring [6], floods are prevalent across the globe with intensity occurring in both Northern and Southern Hemispheres. For example, Herring [6] reported that heavy rainfall in Brazil, Bolivia, and Peru between December 2006 and January 2007 caused heavy floods and landslides.

In the United States of America, Herring also reported that a strong winter storm in late January 2007 produced heavy rainfall across the southern and midwestern United States from Texas to Indiana, causing rivers across the region to burst their banks. In southeastern of India, coastal areas were submerged as a result of floods on November 5, 2006, which swept across Southern India [6]. Elsewhere, in Indonesia, several recent reports by Reliefweb, an information portal of the United Nations Office for the Coordination of Humanitarian Affairs (OCHA), indicated that the flooding in early June 2016 was caused by high tides and heavy rainfall resulting in widespread damages. The ensuing havoc not only triggered the destruction of more than 5900 temporary stalls, but close to 30,000 houses were flooded across 12 provinces in Sumatra, Java, Bali and Nusa Tenggara during the same period [7]. A report in Myanmar on June 9, 2016 also showed heavy rainfall caused by flash floods in some of the regions and townships causing demolished bridges and farmlands with more than 25,000 people displaced [7]. In Philippines, rain brought by the winds from southwestern Monsoon in early August 2016 precipitated floods in several areas, including Manila, with at least 5 fatalities and over 50,000 rendered homeless [8].

In West Africa, more than 200 people were killed and over 50,000 subjected to homelessness as a result of torrential rainfall, which swept through the region from August 4 to 10, 2016, causing Niger and Senegal Rivers to swell up its banks, and with Nigeria, Senegal, Mali, Niger, Burkina Faso receiving the most casualties [9]. According to OCHA, each year, billions of dollars are spent to rebuild flood-related damages in the El Niño affected regions. From 2015 to 2016, 
for example, projected humanitarian needs and the response for millions of people were displaced by El Niño-related floods in 19 countries covering Central America, East Africa (particularly Ethiopia), the Pacific and Southern Africa, costing \$3.9 billion [10].

\section{Visualization of Flood Using Geospatial Technologies}

Several studies have used geospatial technologies to support flood-mitigation related decision-making and management [11] [12] [13] [14] [15]. Early work of Twumasi and Asomani-Boateng [16] used GIS and other technologies for mapping urban flood zones in Accra, Ghana. Results of the study revealed notable flood risk zones and watercourses. Cox and James [17] used ArcGIS 3D Analyst extension's ArcScene application software to create a 3D visualization model that showed parts of Davenport, Iowa that would be submerged at different flood stages. The enquiry helped the city's staff and council to visualize data on how floodwater could affect specific areas of the city at any flood stage. In another study, Rasid and Pramanik [18] used the visual interpretation of National Oceanic and Atmospheric Administration (NOAA's) Advanced Very High Resolution Radiometer (AVHRR) satellite data channels 1 and 2 for August 18, 1987 and September 241988 to delineate flood areas in Bangladesh. Results showed overestimated flood areas by $5 \%$ to $10 \%$ using visual interpretation compared to digitally analyzed data. Other studies have also demonstrated the efficacy of using spatial technologies in delineating flood extent in different areas [19]-[24].

Remote sensing and GIS have found widespread applications in the analysis of visualized impacts of damages caused by floods to both cultural and natural features. In Pakistan, for example, Haq et al. [25] successfully integrated GIS with NASA's Moderate Resolution Imaging Spectro-radiometer (MODIS) onboard Aqua and Terra 2011 images to assess the damages caused by flash flooding in the province of Sindh. In Muscat, Oman, Azaz [26] acquired two temporal IKONOS satellite images on June 5, 2007, which included one image before Cyclone Gonu and one after to assess the damage caused by associated flooding and damages.

With issues identified herein, this paper analyzes how climate change induced flooding impacts the South African region using GIS and remote sensing tools. Emphasis is on the issues, impacts, trends, and factors responsible for the problems. In terms of the objectives, the primary aim of this study is to use remote sensing and GIS data to visualize the impact of climate change hazards caused by floods in Southern Africa. The secondary objective is to design a model to assist decision makers, while the third objective is to develop a framework to track the factors and plan for the mitigation of future occurrences.

\section{Methodology}

\subsection{Study Area}

Southern Africa occupies the southernmost parts of the continent of Africa. It is 
one of the most economic and geo-political sub-groupings of Africa. Southern Africa encompasses 10 countries. These include Angola, Botswana, Lesotho, Malawi, Mozambique, Namibia, South Africa, Swaziland, Zambia, and Zimbabwe. For the purpose of this paper, the region of interest comprises the countries of Zimbabwe, Malawi, and Mozambique (Figure 1). To aid our discussions, some references will be made to the entire region in order to help us understand the impact and influence of natural and cultural features in relation to climate change.

Southern Africa, as in most regions in the world affected by flood and change in global weather patterns, has been experiencing flood for more than two decades [2]. These floods have been exacerbated in recent years by a change in the global weather pattern which cools ocean waters in the equatorial Pacific and changes rainfall patterns across the world known as La Niña [27] [28] [29]. In December 2007 and 2008, La Niña resulted in increased rainfall over Southern Africa causing floods and extensive damage to crops, livestock, and infrastructure (Figure 2). For example, in 2000 and subsequent Mozambique floods, heavy rainfall caused Limpopo River to overflow its bank. Homes and cropland were inundated and destroyed [30] [31]. The flood also affected Malawi and Zimbabwe with millions of property destroyed and thousands of people displaced (Figure 2). Some of the most serious floods, which occurred in 2009, 2010, 2011 and 2015, may have been enhanced by La Niña with cooling of ocean waters in

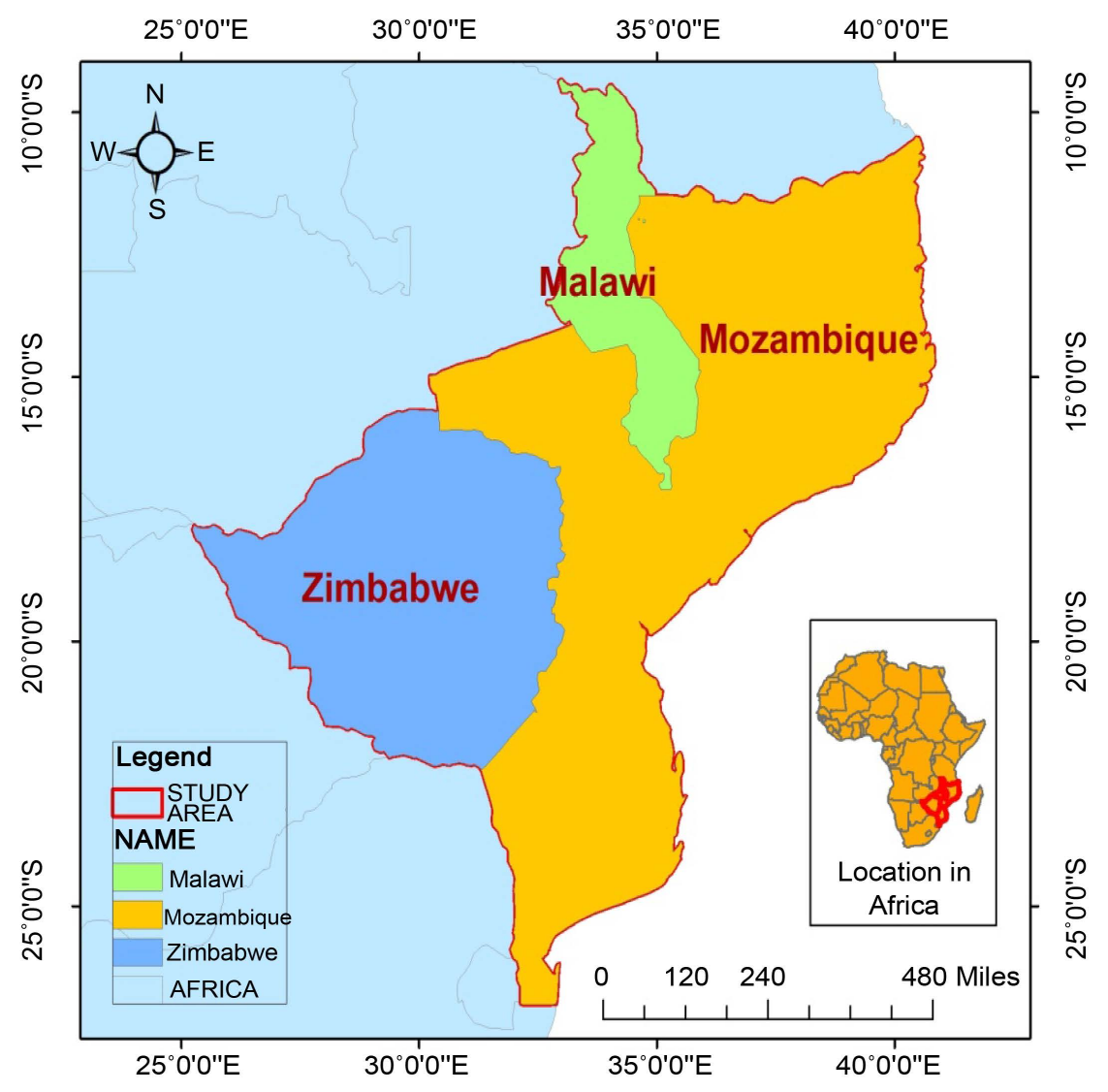

Figure 1. The study area. 


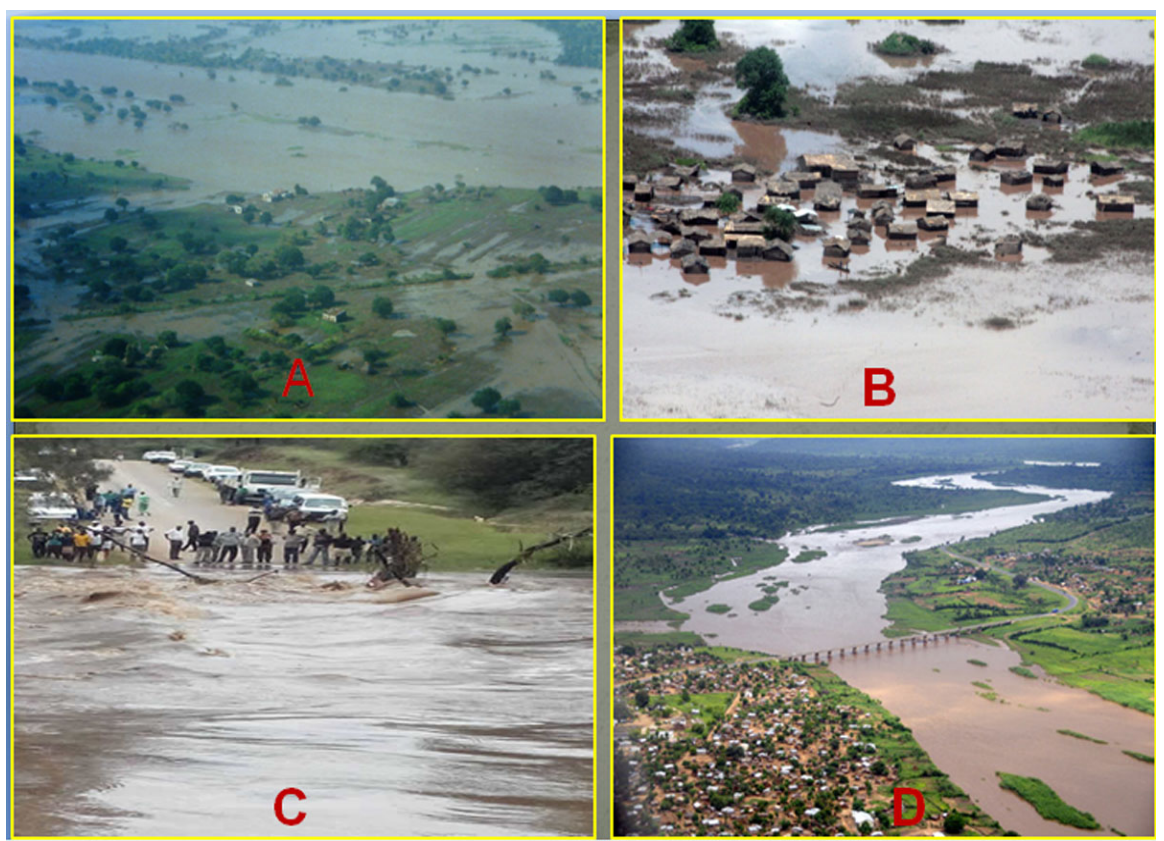

Figure 2. Flash floods in the study area. Image A: Mozambique floods on January 1, 2008. Heavy rainfall caused Limpopo River to overflow its bank. Homes and cropland were destroyed. Image courtesy [31]. Image B: Flooding in Malawi in January 2015. Shown are submerged houses, roads and farmland. Image courtesy [32]. Image C: Gwanda, Zimbabwe. Bridge destroyed as a result of heavy rainfall on February 26, 2014. Photo courtesy [33]. Image D: Mozambique flood on January 12, 2008. An aerial view shows floodwaters near the bridge over the Zambezi River in Tete. Photo Courtesy of [34].

the equatorial Pacific and changes in rainfall patterns across the world [27] [28] [29] [35] [36].

The study area is home to numerous major and minor watercourses and basins. The drainage systems form part of the entire systems in Southern Africa region (Figure 3 and Figure 4). Major watercourses include Zambezi, Shire, Licungo, Buzi, Save and Limpopo rivers. Many of these watercourses have tributaries which flow into the main rivers (Figure 4). For example, Zambezi River has many tributaries such as Cuacua, Zangue, Shire, Pompue, Luala, Revubue and Luia. In the southwestern part of Mozambique, Limpopo River also has many tributaries. Some of these include the rivers: Changane, Olifants, Maxim, Chopes, Mwenezi, Babye and Changane. The flow of two major rivers, Zambezi and Limpopo exhibit dendritic patterns to form large watersheds in the study area.

Majority of the study area lies in the equatorial climate region. Hence, it experiences substantial precipitation ranging between 60 and $180 \mathrm{~mm}$ per year [37]. Rainfall is further enhanced by the Sub-Tropical Eastern Continental Moist Maritime System, Inter-tropical Convergence Zone and global weather pattern known as La Niña [27] [28] [29] [37].

\subsection{Data Acquisition}

To visualize the impact of climate change caused by floods in the study area sets 
Y. A. Twumasi et al.

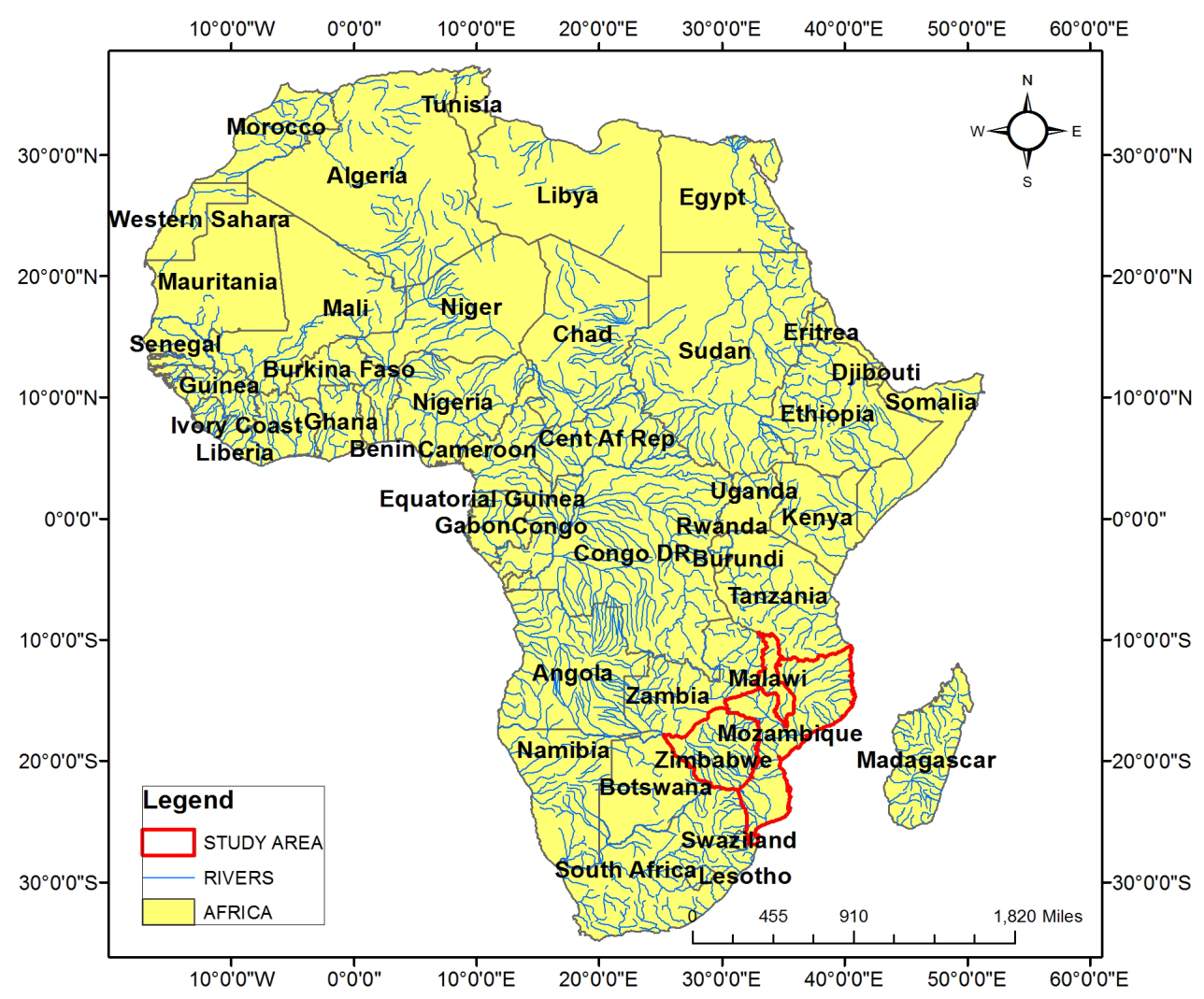

Figure 3. Entire Africa drainage system.

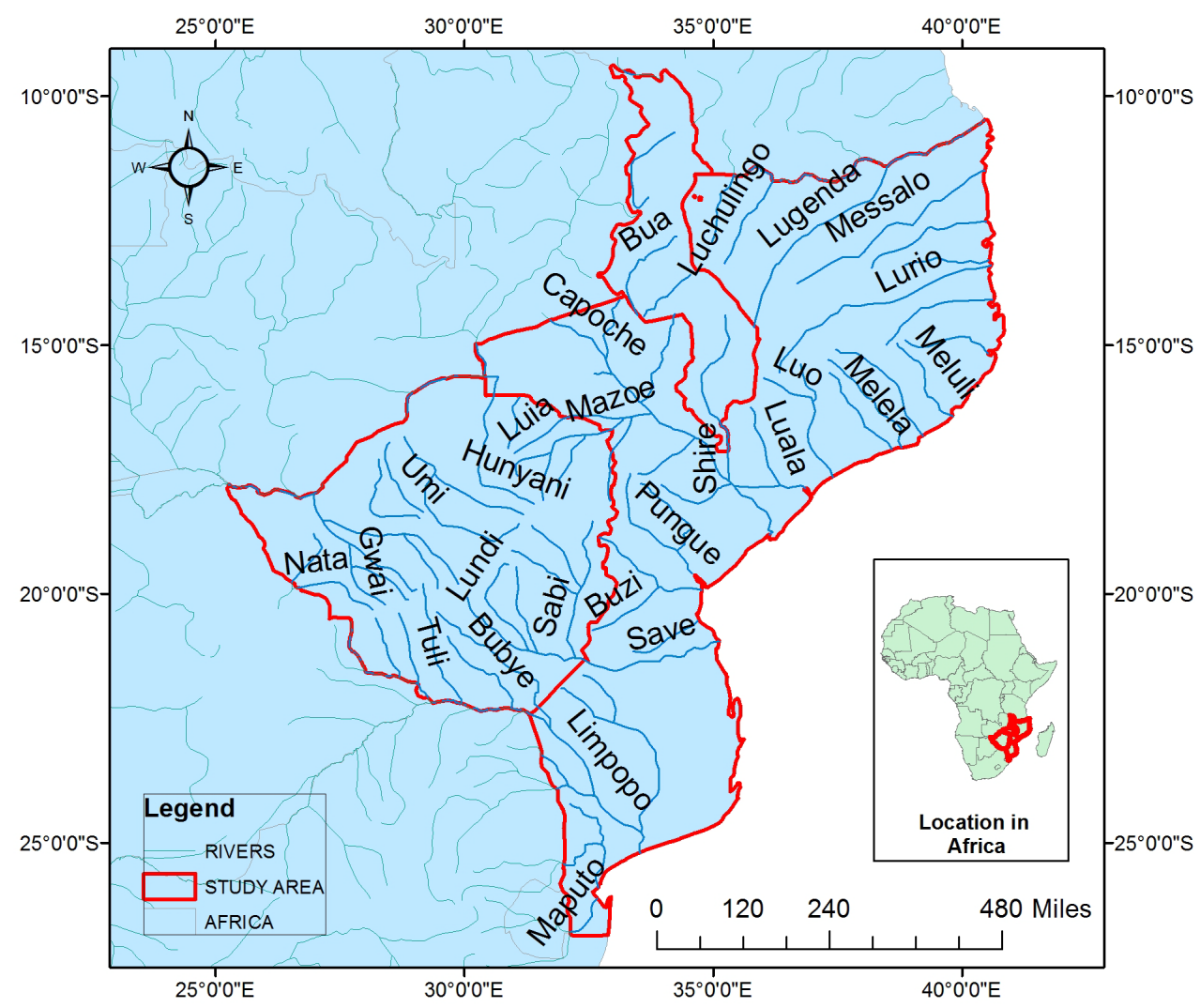

Figure 4. Drainage system in the study area. 
of satellite data were obtained from the United States Geological Survey (USGS)'s imagery website. This consists of Landsat Enhanced Thematic Mapper Plus (ETM+) WRS-2 satellite images acquired on November 29, 2009; August 22, 1999 and, December 30, 2000. The searched area is shown in Figure 5. Additional Moderate Resolution Imaging Spectroradiometer (MODIS) satellite data covering the study area was obtained from NASA's Earth Observatory website which includes the following dates: March 1, 2000, February 11, 2005; January 25, 2013; February 1, 2014; December 5, 2014 and January 17, 2015. The path and row of the satellite data are 165, 166, 167, 168, 169 and row 070, 071072 , 073, 075 and 076, respectively. Elevation data (SRTM/WRS2), covering the study area, was also obtained from the National Elevation Dataset (NED) produced by the United States Geological Survey (USGS)'s seamless data warehouse.

\subsection{Visual Image Comparison Technique}

In this study, we performed band combinations to help us distinguish and interpret environmental features on the ground (i.e. urban areas, vegetation, flooded areas/water bodies) for visualization purpose. Visual image comparison technique was also used in carrying out the investigation. Before proceeding to the analysis, it is important to explain concepts associated with the visual image comparison technique. This is one of the image interpretation techniques used in remote sensing to identify differences in a pair of images acquired over the same area through visual means. Both thematic and metric information can be extracted from remote sensing data through either visual image interpretation or digital image analysis techniques [38]. This method has been widely used by researchers studying land cover change detection or multi-temporal change analysis studies in a variety of geographical environments [39] [40] [41] [42].

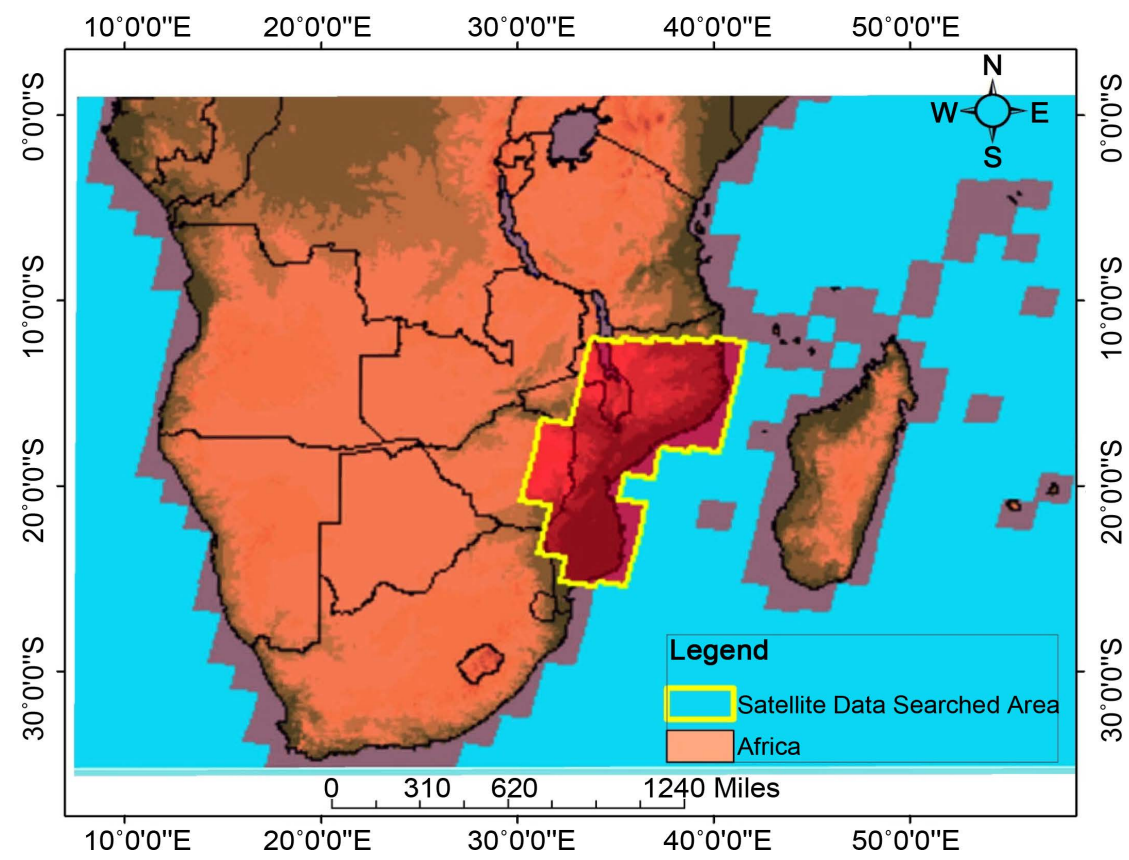

Figure 5. Satellite data searched area. 


\subsection{Data Processing}

\subsubsection{Satellite Data}

To ensure timely handling of the vast network of digital information, ERDAS Imagine (version 2010 of the image processing software package) was used in this enquiry. The Landsat ETM+ images were imported into ERDAS Imagine as a single band using ERDAS native file format GEOTIFF. This was followed by combining all eight of the bands by employing ERDAS Imagine Layer Stack modules. Additionally, altogether, the images were geometrically corrected to remove, haze, scan lines and speckles, and then referenced to Southern African ground-based Geographic: Lat/Lon coordinate system and WGS 84 Datum. From there, all images were mosaicked and later subset using ERDAS Imagine Area of Interest Tool (AOI) to emphasize the study area. Data from six spectral bands of Landsat ETM+, covering the visible and near infrared sections of the electromagnetic spectrum, were further used in the analysis. The visual comparison technique of the acquired images before and after the flood was used to show the flooded areas.

\subsubsection{Elevation Data}

The elevation data was imported into the Global Mapper evaluation software to create the Digital Elevation Model (DEM) surface of the entire study area. The idea was to be able to determine the entire elevation of the study area to identify areas prone to flooding.

\section{Results and Discussion}

Figure 6 shows the elevation map of the study area and the neighboring countries.

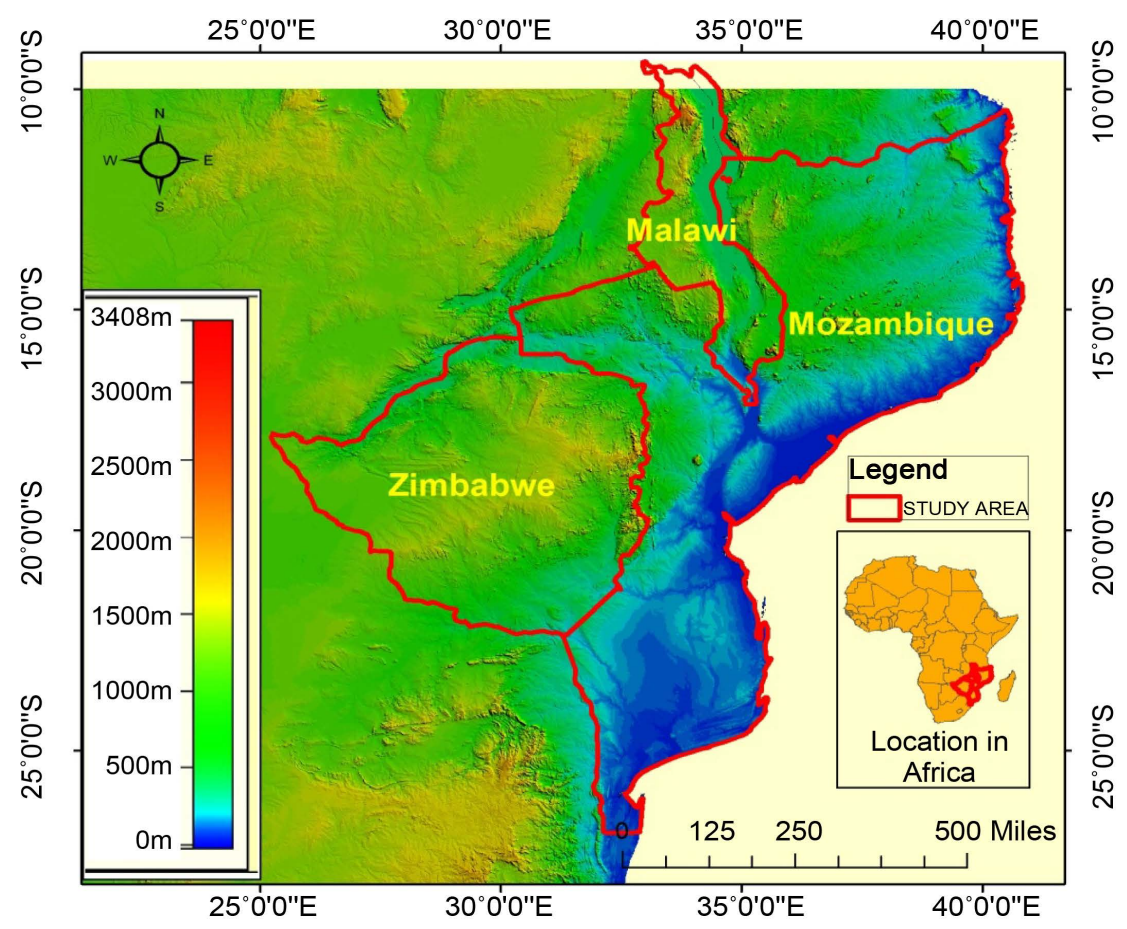

Figure 6. Elevation map of the study area and the neighboring countries. 
The blue color represents low elevation areas, while brown and pink represents high elevation. Red polygon color of the study area is overlaid onto the elevation map.

Figure 7 displays an image of Mozambique before and after the floods. The pair of images was captured by the MODIS satellite on February 1, 2014 (before the floods in image A) and January 17, 2015 (during the floods in image B). The areas shown in these images are around the town of Quelemani located along the coast and Licungo River on the north of the coastline. Also shown in Figure 7, on the top right corner, is the location of Licungo River and the city of Quelemani from Google Maps. Figure 8 represents ETM+ image covering Malawi and Mozambique. This image was captured on December 14, 2014 before the floods and January 25, 2015 during the floods. The Short Wave Infrared (SWIR) color composited image was created by combining the red, green, and blue wavelengths (ETM+ bands 5, 4, and 2). Figure 9 represent Mozambique coastline. This shows a pair of images prior to the flooding acquired on August 22, 1999 and an image showing flooding along Mozambique coastline acquired on March 1, 2000. These image shows false color composite of the study area, displaying channel $4(0.76-0.90 \mu \mathrm{m})$ in red, channel $3(0.63-0.69 \mu \mathrm{m})$ in green, and channel $2(0.52-0.60 \mu \mathrm{m})$ in blue.

Flooded areas along the town of Chokwe and Limpopo River are shown in Figure 10. This represents a pair of images from MODIS satellite: image A, captured on February 11, 2005 (before the floods) and image B, captured on January 25, 2013 (during the floods). This image shows false color composite dimensions

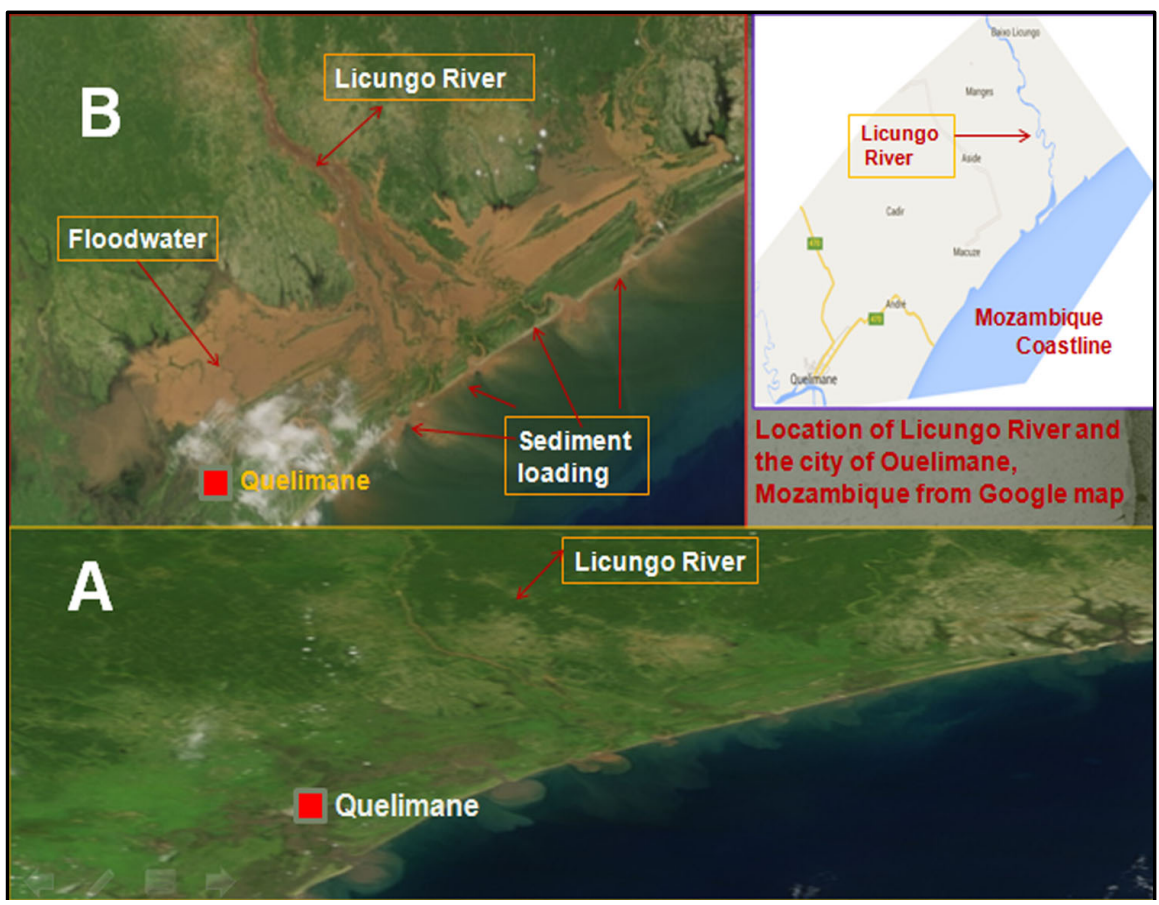

Figure 7. Image of mozambique before and after floods. Image A February 1, 2014 (before the floods) and Image B January 17, 2015 (during the floods) [43]. Heavy rainfall in early January through March 2015 caused Licungo River in mozambique to over flow its bank. 


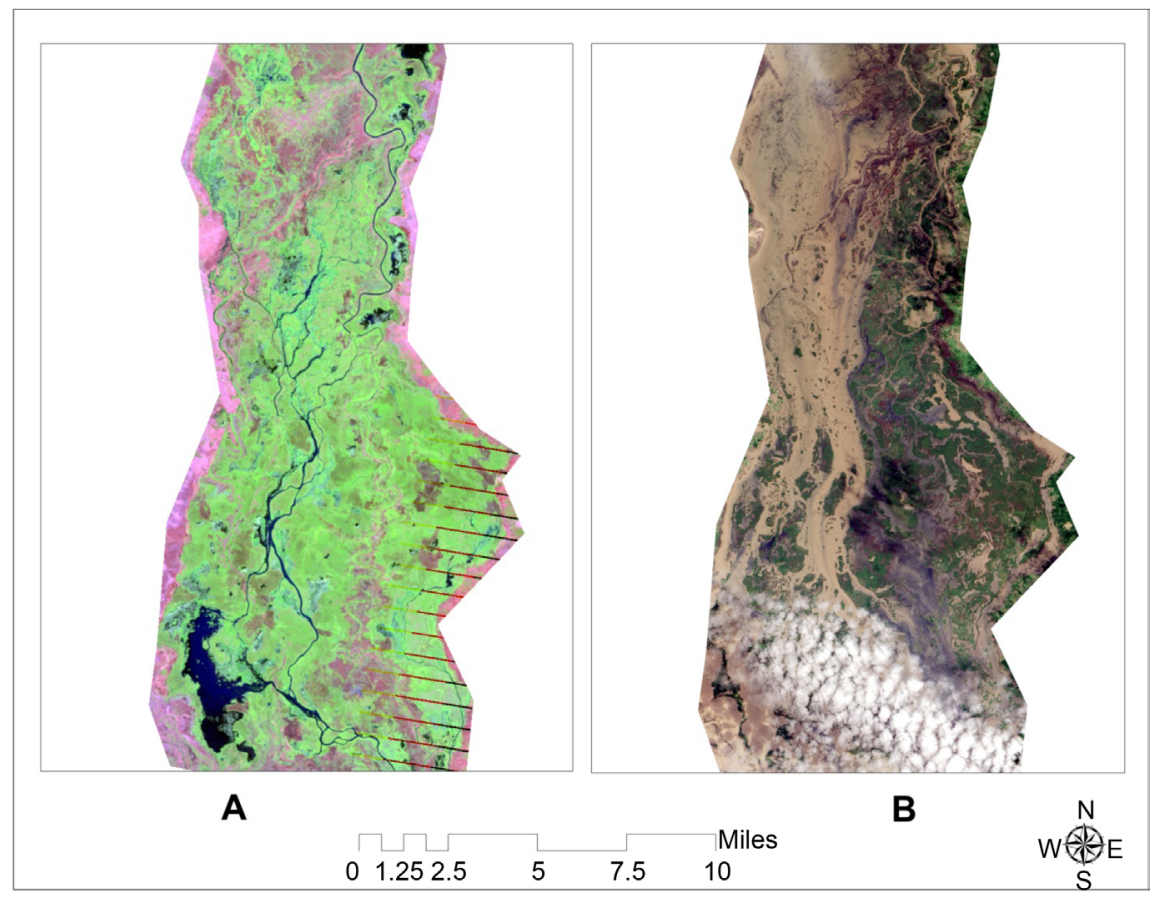

Figure 8. Image covering malawi and mozambique. image $\mathrm{A}$ is landsat $14^{\text {th }}$ December, 2014 ETM+ before the floods and Image B during the flood captured on 25th January 2015. The path and row of the image are 167 and 72 . This Short Wave Infrared (SWIR) color composite image was created by combining the red, green, and blue wavelength (ETM+ bands 5, 4, and 2). Evidence of flooding is captured in the image with color shade of tan in Image B representing areas of floods with damages to the vegetation and other cultural features.
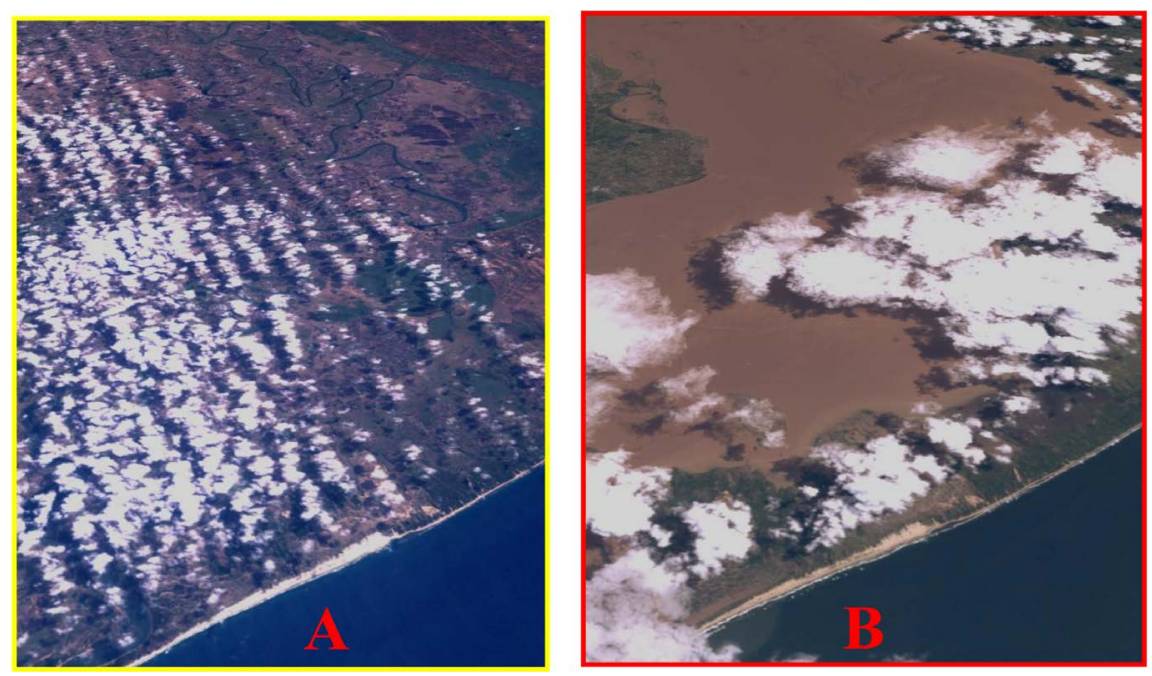

Figure 9. Image of Mozambique coastline. Image A: Mozambique coastline prior to flooding acquired on August 22, 1999. Image B: Flooded Mozambique coastline acquired on March 1, 2000 [44]. Image shown in pink-tan color indicates water is rich in sediments and white color represents clouds and green for vegetation. In the flooded area, all the vegetation and ecosystem destroyed.

of the study area. From the configurations, water bodies appear dark blue, healthy vegetation is characterized as green, bare fields and freshly exposed soil 


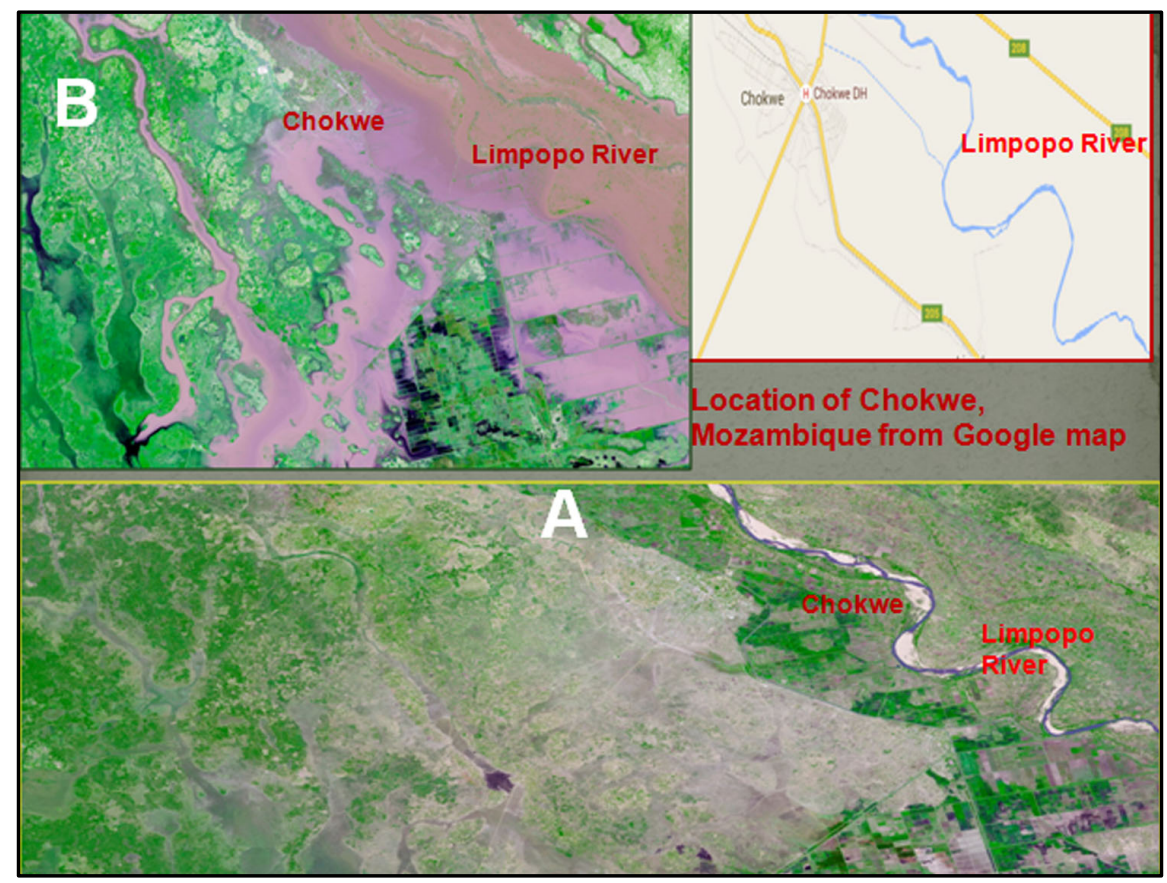

Figure 10. Flooded areas along the town of Choke. Image A February 11, 2005 (before the floods) and Image B January 25, 2013 (during the floods) [45]. Heavy rainfall in early January through March 2013 caused Limpopo River to over flow its bank causing severe damage to the city of Chokwe in Southern Mozambique. Major agricultural fields and homes were inundated and destroyed.

are pink, and concrete is grey. Also, on the top right corner (northeast) of Figure 10, the locations of the town of Chokwe and Limpopo River from Google map are displayed.

From the processed elevation map in Figure 6, majority of the study area lies in low-lying areas, especially most of Mozambique and southern Zimbabwe and Malawi. In most situations, low lying areas are generally more prone to flooding than communities located in higher ground. In Figures 7-9, there are notable evidence of environmental damage to the vegetation and the beaches along the coast as a result of the flooding. The tan color in image B clearly shows the extent of the flood water. It also suggests that the water is full of sediments. Also notable in Figure 7, in image B, the Licungo River carries sediment loads from the upstream to lower areas along the coast of Mozambique. The velocity of such volume and the frequency under those circumstances has caused the acceleration of sediments to build up in the area. In Figure 8, vegetation and farmland in the flooded areas were destroyed. These are areas in Mozambique, Malawi along the confluence of Shire and Zambezi Rivers basins, as well as the eastern part of Zimbabwe bordering Malawi. From image B in Figure 8, one could see flooded areas in a tan color along the western side of Shire River north of Zambezi River. In Figure 10, Image B also shows serious environmental and cultural damages sustained as a result of flash flooding prompted and caused by heavy rainfall. Intense precipitation during the January 23, 2013 rains upstream in Zimbabwe and South Africa triggered the overflow of Limpopo River inflicting 
serious damages to the population and environment [46] [47]. As reported in January 2013 by the largest United Nations humanitarian information portal in the world, Reliefweb, the surrounding villages in and around Chokwe city in Xai-Xai district of Mozambique were inundated by flood waters along Limpopo River. In Chokwe, many cultural features such as roads and railroads were inundated and destroyed, including highway 208 which runs along the east bank of the Limpopo River with more than 80,000 people rendered homeless [46] [47]. As captured by the Landsat ETM+ satellite image in Figure 10, agricultural farmlands, bridges and homes were all inundated.

From the drainage map in Figure 4, the study area is home to many watersheds. These watercourses rise quickly and exhibit a large increase in stream flow when a major rainstorm hits the watershed causing lots of damages to homes, infrastructure and agricultural land.

\section{Factors Fuelling Recurrent Exposure to Flooding}

In terms of factors responsible for the repeated exposure to climate change induced flooding in the Southern African region it is evident that they do not operate in a vacuum. They are linked to socio-economic elements of poor planning and land use, the sparse use of advanced early warning systems and physical and natural elements and demographic changes. Detailed analysis of these elements is presented in the following paragraphs.

\subsection{Poor Planning and Land Use}

Part of the mantra of planning is ensuring the quality of life and the environment of communities through orderly development as dictated through various planning initiatives using master planning and comprehensive plans. In those settings, communities are offered opportunities to chart the direction of future economic and physical development along the location of protected areas and other land uses, such as agriculture, rural and residential, industrial and transportation. Here, the emphasis revolves around ensuring the preservation of farm land and natural areas and the protection of communities from natural hazards by not exposing cities to flood prone areas in residential development. Limiting physical elements occurs such as elevation, topography and any vulnerability in the issuance of development permit. Some have also gone as far as integrating storm levels from category 1 - 5 into rescue plans should the scale tip towards the deadliest levels. The common practice of using zoning requires that the planned land use be conducive, safe and livable enough for the citizens. However, that is not always the case, especially in communities where long term visions reflect unprecedented growth poised to outpace surrounding neighbors. In such settings, sometimes land use developments tend to occur in a haphazard and uncontrolled fashion with exposure of communities to hazard prone areas that are often at the epicenters of inclement weather disasters, such as the ones witnessed in the southern African region. The recurrent nature of resulted risks and poor planning and land use are some of the underlying factors fuelling the ex- 
posure of citizens and the surrounding ecology to damages unleashed from climate change [48].

\subsection{The Sparse Use of Advanced Early Warning Systems}

Judging from the category 9.0 tsunami earth quake disasters in 2004 and the 2011 affecting the nations by the Indian Ocean and a mega-magnitude 9 earth quake that jolted the Tohoku region of north western Japan [48], it is clear that having a head start of impending disasters through early warning system capabilities remains effective and essential in minimizing damages and fatalities in communities at risk. In an era in which all nooks and corners of the globe are exposed to recurrent ravages from climatic forces. The recourse and acquisition of advanced early warning electronic systems that track and predict the nature and extent of impending weather hazards are now highly essential in making a difference towards environmental emergencies in terms of who lives and who does not in communities at risk.

The use of early warning systems is a major lifeline in the mitigation of hazards induced from increment uncertainties. It offers those who have enough time to make critical adjustments necessary to constantly track the scale, velocity and paths of approaching storms. This results in improving their organizational capability by setting up their respective temporary command control centers for monitoring and implementing evacuation priorities. With accurate interpretation of the scale or level and direction of the approaching storms, officials are better placed in formulating evacuation measures for movement towards storm shelters in the immediate surrounding and safe grounds. Considering that most of the states in the southern African region lack this capability, casualties and damages have surged over the years. If these nations had been in possession of advanced early warning systems, it would have eased rescue efforts and minimized the damages. As a result, the sparse use of early warning system stands as a major element limiting the containment of inclement weather hazards in the Southern African region.

\subsection{Physical and Natural Factors: The Growing Incidence of El Nino}

Just as in the other areas of the globe, the Southern African region is characterized by a major vulnerability to flood and changing global weather configurations. It has gradually become an epicenter of major flooding in the last twenty years due to intensified floods by a variability change in global weather pattern referred to as La Niña [27] [28] [29]. In the beginning in December of 2007 through 2008, La Niña precipitated widespread downpour over Southern African triggering floods and heavy damages to crop yields, animal husbandry and infrastructure (Figure 2). For example, in 2000 and subsequent Mozambique floods, heavy rainfall forced the Limpopo River to crest and overflow its bank. As a result, numerous properties including residential households and farm were severely flooded and devastated [30] [31]. The flood also impacted Malawi and 
Zimbabwe where citizens endured millions of property destruction and the displacement of thousands of individuals (Figure 2). Furthermore, much of the most severe floods which landed in 2009, 2010, 2011 and 2015 appear to have been triggered by La Niña, which often lower the temperature of ocean waters along the equatorial Pacific and fluctuates rainfall patterns across the world [27] [28] [29] [31] [33] [34]. In addition, the topography of some at risk communities in the Southern African region should not be overlooked, where the epicenters of the floods appear to be the low lying areas. In the context of climatic variability patterns associated with global inclement weather hazards, human settlements and land uses adjacent to low lining localities like those in the South African region remain vulnerable to the damages induced from violent floods.

\subsection{Demography}

In both developed and developing nations, coastal areas contain the most rapidly growing towns and cities. As a result, pressures due to increased population in some of the coastal zones of the Southern African region continue to fuel unprecedented shoreline development, putting populations, tourists and properties at increased danger of massive storm surges and flooding. This is evident with the pace at which the overall population figures of the region went from over 63 million inhabitants in 2017 at an average growth rate of $2.93 \%$ between 2011 through 2017 (Table 1). Being one of the largest growth rates in the world during these periods, each country (Malawi, Mozambique and Zimbabwe) posted an average of single digit population growth rates in the order of $3.09 \%-2.83 \%$ and $2.87 \%$ that exceeded the levels of others in the globe (Table 2). At the same time, the coastal regions of the study area are some of the most exotic and eye-catching places to visit and live in resulting in millions of visitors who visit these coastlines each year in the summer. In the process, coastal residency tends to grow. The fact that many find the weather in such place stay appealing does their increases the attractiveness and liability of coastal areas of the southern African region as epicenters of flooding. Overall, coastlines like the ones in the study area are a preferred destination for human settlements. They provide outdoor and ecotourism opportunities that often require new development in the form of new hotels, roads, etc. Due to the appealing nature of coastal settlements in the face of inclement events, coastal communities have grown to high heights as shown with novel resorts and seaside facilities at unprecedented levels. In the process, many individuals and infrastructure facilities are not only threatened by damaging force of floods, but they remain now in harm's more than ever. This

Table 1. The combined population of the region in 2017.

\begin{tabular}{cc}
\hline Nations & Population \\
\hline Malawi & $18,008,081$ \\
Mozambique & $29,161,872$ \\
Zimbabwe & $16,111,699$ \\
Total & $\mathbf{6 3 , 2 8 1 , 6 5 2}$ \\
\hline
\end{tabular}


Table 2. The population changes in the South African region 2011-2017.

\begin{tabular}{|c|c|c|}
\hline \multicolumn{3}{|c|}{ Malawi } \\
\hline Year & Population & Growth Rate \\
\hline 2011 & $14,998,319$ & $3.09 \%$ \\
\hline 2012 & $15,463,625$ & $3.10 \%$ \\
\hline 2013 & $15,945,281$ & $3.11 \%$ \\
\hline 2014 & $16,442,690$ & $3.12 \%$ \\
\hline 2015 & $16,955,243$ & $3.12 \%$ \\
\hline 2016 & $17,473,734$ & $3.06 \%$ \\
\hline 2017 & $18,008,081$ & $3.06 \%$ \\
\hline \multicolumn{3}{|c|}{ Mozambique } \\
\hline Year & Population & Growth Rate \\
\hline 2011 & $24,669,189$ & $2.85 \%$ \\
\hline 2012 & $25,374,925$ & $2.86 \%$ \\
\hline 2013 & $26,100,054$ & $2.86 \%$ \\
\hline 2014 & $26,841,728$ & $2.84 \%$ \\
\hline 2015 & $27,597,070$ & $2.81 \%$ \\
\hline 2016 & $28,368,684$ & $2.80 \%$ \\
\hline 2017 & $29,161,872$ & $2.80 \%$ \\
\hline \multicolumn{3}{|c|}{ Zimbabwe } \\
\hline Year & Population & Growth Rate \\
\hline 2011 & $14,114,745$ & $1.93 \%$ \\
\hline 2012 & $14,410,537$ & $2.10 \%$ \\
\hline 2013 & $14,731,787$ & $2.23 \%$ \\
\hline 2014 & $15,071,974$ & $2.31 \%$ \\
\hline 2015 & $15,424,303$ & $2.34 \%$ \\
\hline 2016 & $15,764,255$ & $2.20 \%$ \\
\hline 2017 & $16,111,699$ & $2.20 \%$ \\
\hline
\end{tabular}

Source: [49].

applies tremendous pressure on the carrying capacity of the ecosystem which in turn increases the vulnerability of population centers to any potential inclement weather event in an unstable environment [49].

\section{The Small Area (City) Analysis}

At the city level a total of 7,951,179 inhabitants in selected coastal and inland cities of the study area could be at risk in the three countries based on current projections (Table 3).

Amongst the three nations in the region, Mozambique has 3,101,816 million people along its coasts and there are about 3,214,409 to 1,634,954 million people in some of the largest cities in Zimbabwe and Malawi under the direct exposure of inclement weather hazards that should be taken quite seriously. Mozambique's coastal cities, which are the residence to 60 percent of the nation's inhabi- 
Table 3. The population distribution at the city level in 2016.

\begin{tabular}{|c|c|}
\hline \multicolumn{2}{|c|}{ Population Distribution of Mozambique Coastal Cities, 2016} \\
\hline City & Population \\
\hline Maputo & $1,191,613$ \\
\hline Matola & 675,422 \\
\hline Beira & 530,604 \\
\hline Nacala & 224,795 \\
\hline Quelimane & 188,964 \\
\hline Pemba & 108,737 \\
\hline Xai-Xai & 127,366 \\
\hline Ilha deMocambique & 54,315 \\
\hline Total & $3,101,816$ \\
\hline \multicolumn{2}{|c|}{ Population Distribution of Zimbabwe Major Cities, 2016} \\
\hline City & Population \\
\hline Harare & $1,542,813$ \\
\hline Bulawayo & 699,385 \\
\hline Chitungwiza & 340,360 \\
\hline Mutare & 184,205 \\
\hline Gweru & 146,073 \\
\hline Epworth & 123,250 \\
\hline Kwekwe & 99,149 \\
\hline Kadoma & 79,174 \\
\hline Total & $3,214,409$ \\
\hline \multicolumn{2}{|c|}{ Population Distribution For Malawi Largest Cities, 2016} \\
\hline City & Population \\
\hline Lilongwe & 646,750 \\
\hline Blantyre & 584,877 \\
\hline Mzuzu & 175,345 \\
\hline Zomba & 80,932 \\
\hline Kasungu & 42,555 \\
\hline Mangochi & 40,236 \\
\hline Karonga & 34,207 \\
\hline Salima & 30,052 \\
\hline Total & $1,634,954$ \\
\hline
\end{tabular}

Source: [50] [51] [52].

tants, are largely the economic engines driving the country's market activities. Nonetheless, given their settings, they are among the most susceptible towns in Africa unprotected from sea level rises, natural calamities and the impacts of climate change (Figure 6). Such cyclical events like cyclones and tropical storms can extremely affect city environments, biodiversity, and the wellbeing of local areas [53] [54]. Furthermore, Mozambique being one of the most at risk coastal zones in Africa continues be at the epicenter of climate change induced natural 
disasters. In fact, 15 of the 56 tropical cyclones and tropical storms that landed into the Mozambique waterway between 1980-2007 inflicted a direct hit on the coasts. With that, coastal inundation not only remained a major concern for citizens for nearly two decades, but in the absence of mitigation measures in the next five decades many coastal cities like Nacala, Beira and Quelimane will eventually varnish. Any situation like that will not only dislocate the populace, but the nation's economic structure could be destroyed. In the coastal region close to 2.5 million inhabitants thrive on irrigated agriculture and fishing. But then again, the influx of people into to coastal cities stretched beyond limits puts additional individuals, physical infrastructure and facilities in danger. In the nation's capital city of Maputo, the port, railway network and oil facilities, located on a river mouth, are also vulnerable to flooding. It has also been shown that Mozambique could experience about 50\% loss of its coastal gross domestic product (GDP) under current conditions [55]. Considering the local climatic variations in Zimbabwe and Malawi, the major southern and Zambezi valley cities for Zimbabwe will experience severe heat and aridity coupled with torrential rains in the eastern highlands of the country. Similar climatic variability also holds for Malawi where the cities of Lilongwe, Blantyre, Zomba, Muzuzu, Karonga, Kasungu and others are all vulnerable to climate change due to heavy flooding during the rainy season given vicinity to Lake Malawi, the Zambezi River and a handful of other river tributaries and lakes.

\section{Conclusions}

This study has shown that GIS and remote sensing data could play an important role in mapping flood-induced risks by changes in weather pattern. Indeed, GIS and satellite data have proved effective in this study. These methodological tools were not only instrumental in the analytical visualization of areas affected by flooding waters, but they pinpointed environmental and cultural infrastructure damages sustained in the study area over time. As the study area and the rest of the region continue to experience flood-related disaster every year, the paper shows that the extent and nature of recurrent disasters in the region do not operate in vacuum. They are attributed to several socio-economic and physical elements characterized by poor planning and land use, changing demography, sparse use of advanced early warning emergency electronic systems, the threats of El-Nina, and the topography of the countries. Furthermore, there is a growing need for the adoption of appropriate and effective policy options to safeguard vulnerable communities in the study area. With a focus on dealing with flooding or other environmental hazards germane to the region, such policy approach will help minimize the exposure to danger posed to surrounding ecology through recurrent damages and loss of life. As a result, various governments in the study area could relocate much of the population or build drainage ditches on the flat plains identified in this study to accommodate flood flows coupled with temporary flood resistant, temporary shelters to house flood victims in the event of disasters. This could completely or partially minimize the damaging 
impact of any flooding. However, any options that involve population relocation may require consent from individuals and groups affected; otherwise the relocation program may fail.

There is also the need to design and build a comprehensive Regional Emergency Information System (REIS) with support from the governments in the study area and the neighboring countries. REIS would require integrating GIS and remote sensing data, climate data, national and local-level weather forecast, and hydrological data including information on the river flow into one system. Digital devices should have the capability to track and characterize the scale or level of impending disasters under various categories as done in the United States in advance or before they make landing. It must be synchronized with local comprehensive plans in built environments and coastal communities along the shorelines to keep those areas continually livable year after year.

This system should also involve locals at all levels ranging from the community/local and regional/national level. Locals should be trained on how to handle this system in an emergency situation. Due to cultural and linguistic differences in the study area and the neighboring countries, brochures and information related to the emergency system should be translated into the local dialects for better understanding of the system by locals and the community. Information related to the system and flood-related emergencies should also be broadcasted in the local and national media outlets: radio, television and newspapers in the local languages. Developing such a system will go a long way to offer decision makers access to the appropriate spatial-temporal data for monitoring emergencies related to seasonal floods in the region.

\section{References}

[1] Huber, D.G. and Gulledge, J. (2011) Extreme Weather and Climate Change: Understanding the Link and Managing the Risk. Center for Climate and Energy Solution, Arlington, Virginia.

https://www.c2es.org/docUploads/white-paper-extreme-weather-climate-change-u nderstanding-link-managing-ri sk.pdf

[2] Twumasi, Y.A., Osei, A., Petja, B.M. and Ayala-Silva, T. (2015) The Impact of Climate Change on Seasonal Floods in Southern Africa. Proceedings of the 4th International Climate Change and Population Conference on Africa: "Climate Change, Sustainable Innovation and Partnerships”, Accra, 29-31 July 2015.

[3] Upton, J. (2016) Louisiana Floods Directly Linked to Climate Change. http://www.climatecentral.org/news/louisiana-floods-directly-linked-to-climate-cha nge-20671

[4] Akeh, G.I. and Mshelia, A.D. (2016) Climate Change and Urban Flooding: Implications for Nigeria's Built Environment. MOJ Ecology \& Environmental Science, 1, 14.

[5] Church, J.A., Woodworth, P.L., Aarup, T. and Wilson, W.S., Eds. (2010) Understanding Sea-Level Rise and Variability. Blackwell, Oxford.

[6] Herring, D. (2007) NASA's Earth Observatory and Natural Hazards. http://earthobservatory.nasa.gov/NaturalHazards/natural_hazards_v2.php3?topic=f $\underline{\text { lood }}$ 
[7] OCHA (United Nations Office for the Coordination of Humanitarian Affairs) (2016) Asia and the Pacific: Weekly Regional Humanitarian Snapshot.

http://reliefweb.int/report/myanmar/asia-and-pacific-weekly-regional-humanitaria n-snapshot-7-13-june-2016

[8] Davies, R. (2016) Philippines-5 Dead and 50,000 Displaced after Floods in Manla, Central Luzon and Calabarzon.

http://floodlist.com/asia/philippines-floods-manila-central-luzon-calabarzon-augus $\underline{\mathrm{t}-2016}$

[9] Davies, R. (2016) WestAfrica-Deadly Floods in Mali and Burkina Faso. http://floodlist.com/africa/west-africa-floods-nigeria-mali-burkina-faso-august-2016

[10] OCHA (United Nations Office for the Coordination of Humanitarian Affairs) (2016) El Niño: Overview of Impact, Projected Humanitarian Needs and Response. https://docs.unocha.org/sites/dms/Documents/OCHA_ElNino_Monthly_Report_2J un20 6.pdf

[11] Wang, Y., Colby, J.D. and Mulcahy, K.A. (2002) An Efficient Method for Mapping Flood Extent in a Coastal Flood Plain Using Landsat TM and DEM Data. International Journal of Remote Sensing, 23, 3681-3696.

https://doi.org/10.1080/01431160110114484

[12] Huali, C., Yuka, I., Marie, S., Tao, S. and Tomochika, T. (2016) Spatial and Temporal Changes in Flood Hazard Potential at Coastal Lowland Area: A Case Study in the Kujukuri Plain, Japan. Natural Hazards, 84, 1513-1527. https://doi.org/10.1007/s11069-016-2495-6

[13] Abdelkareem, M. (2017) Targeting Flash Flood Potential Areas Using Remotely Sensed Data and GIS Techniques. Natural Hazards, 85, 19-37. https://doi.org/10.1007/s11069-016-2556-x

[14] Bu, L., Twumasi, Y.A. and Wang, F. (2017) Visualization of Climate Change Impact on the Mississippi Gulf Coast Area. Proceedings of the 5 th Anniversary HBCU Climate Change Conference, Bridging the Gap between Theory and Experience, New Orleans, Louisiana, 15-19 March 2017.

[15] Rahman, M.S. and Di, L. (2017) The State of the Art of Spaceborne Remote Sensing in Flood Management. Natural Hazards, 85, 1223-1248.

https://doi.org/10.1007/s11069-016-2601-9

[16] Twumasi, Y.A. and Asomani-Boateng, R. (2002) Mapping Seasonal Hazards for Flood Management in Accra, Ghana Using GIS. Proceedings of the IEEE International Geoscience and Remote Sensing Symposium (IGARSS) Conference, Westin Harbour Castle, Toronto, 24-28 June 2002.

http://ieeexplore.ieee.org/xpl/freeabs_all.jsp?arnumber $=1026807$

[17] Cox, D. and James, K. (2009) City of Davenport Uses 3D Visualization to Prepare for Flooding Environmental Observer, Winter.

http://www.esri.com/library/reprints/pdfs/envobsv_davenport.pdf

[18] Rasid, H. and Pramanik, M.A.H. (1990) Visual Interpretation of Satellite Imagery for Monitoring Floods in Bangladesh. Environmental Management, 14, 815-821. https://doi.org/10.1007/BF02394176

[19] Dewan, A.M., Kumamoto, T. and Nishigaki, M. (2006) Flood Hazard Delineation in Greater Dhaka, Bangladesh Using an Integrated GIS and Remote Sensing Approach. Geocarto International, 21, 33-38.

https://doi.org/10.1080/10106040608542381

[20] Martinis, S., Twele, A. and Voigt, S. (2009) Towards Operational Near Real-Time Flood Detection Using a Split-Based Automatic Thresholding Procedure on High Resolution TerraSAR-X Data. Natural Hazards Earth System Science, 9, 303-314. 
http://www.nat-hazards-earth-syst-sci.net/9/303/2009/

[21] Huang, C., Chen, Y. and Wu, J. (2014) Mapping Spatio-Temporal Flood Inundation Dynamics at Large River Basin Scale Using Time-Series Flow Data and MODIS Imagery. International Journal of Applied Earth Observation and Geoinformation, 26, 350-362. https://doi.org/10.1016/j.jag.2013.09.002

[22] Huang, C., Chen, Y., Wu, J., Chen, Z., Li, L., Liu, R. and Yu, J. (2014) Integration of Remotely Sensed Inundation Extent and High-Precision Topographic Data for Mapping Inundation Depth. Proceedings of the IEEE Third International Conference on Agro-Geoinformatics, Beijing, 11-14 August 2014. https://doi.org/10.1109/agro-geoinformatics.2014.6910580

[23] Klemas, V. (2013) Airborne Remote Sensing of Coastal Features and Processes: An Overview. Journal of Coastal Research, 29, 239-255. https://doi.org/10.2112/JCOASTRES-D-12-00107.1

[24] Klemas, V. (2015) Remote Sensing of Floods and Flood-Prone Areas: An Overview. Journal of Coastal Research, 31, 1005-1013. https://doi.org/10.2112/JCOASTRES-D-14-00160.1

[25] Haq, M., Akhtar, M., Muhammad, S., Paras, S. and Rahmatullah, J. (2012) Techniques of Re-Mote Sensing and GIS for Flood Monitoring and Damage Assessment: A Case Study of Sindh Province, Pakistan. The Egyptian Journal of Remote Sensing and Space Sciences, 15, 135-141. https://doi.org/10.1016/j.ejrs.2012.07.002

[26] Azaz, L.K. (2010) Using Remote Sensing and GIS for Damage Assessment after Flooding, the Case of Muscat, Oman after Gonu Tropical Cyclone 2007: Urban Planning Perspective. Proceedings of the REAL CORP, Tagungsband, Vienna, 1820 May 2010. http://programm.corp.at/cdrom2010/papers2010/CORP2010_182.pdf

[27] NOAA (2005) El Niño-Southern Oscillation (ENSO). National Weather Service Climate Prediction Center.

http://www.cpc.ncep.noaa.gov/products/precip/CWlink/MJO/enso.shtml\#educatio nalmaterial

[28] NOAA (2005) El Niño Related Global Temperature and Precipitation Patterns. National Weather Service Climate Prediction Center.

http://www.cpc.ncep.noaa.gov/products/analysis_monitoring/ensocycle/elninosfc.s $\underline{\mathrm{html}}$

[29] Graham, S. (1999) La Niña. NASA's Earth Observatory, EOS Project Science Office. NASA Goddard Space Flight Center. https://earthobservatory.nasa.gov/Features/LaNina/printall.php

[30] Banya, N. (2008) Zimbabwe at Risk of More Southern Africa Floods. http://www.reuters.com/article/2008/01/16/us-africa-floods-idUSL16725819200801 $\underline{16}$

[31] Wikimedia Commons (2015) File: 2000 Floods, Limpopo River (6331098058). https://commons.wikimedia.org/wiki/File:2000_floods,_Limpopo_River_(63310980 58).jpg

[32] Ntonya, G. (2015) Flooding in Malawi. United Nations Development Program (UNDP). https://www.flickr.com/photos/unitednationsdevelopmentprogramme/16194375138

[33] Bulawayo 24 News (2014) Mtshabezi River Bridge Maroons Gwanda Town Again. http://bulawayo24.com/index-id-news-sc-regional-byo-42500.html

[34] Neuenburg, G.L. (2008) Zimbabwe at Risk of More Southern Africa Floods. http://www.reuters.com/article/2008/01/16/us-africa-floods-idUSL16725819200801 16 
[35] Powell, A. (2013) Deadly Floods Hit Mozambique. Voice of America. http://www.voanews.com/content/united-nations-reports-devastating-damages-afte r-mozambique-flood/1595319.html

[36] AllAfrica (2015) Mozambique: Licungo Dropping, But River Basin Still Flooded. http://allafrica.com/stories/201501210335.html

[37] SADC (2012) Climate in Southern Africa. Southern African Development Community. Towards a Common Future. http://www.sadc.int/themes/meteorology-climate/

[38] Awange, L.J. and Kiema, J.B.K. (2013) Environmental Geoinformatics: Monitoring and Management (Environmental Science and Engineering). 2013th Edition. Springer-Verlag, Berlin Heidelberg, 541 p. https://doi.org/10.1007/978-3-642-34085-7

[39] Inglada, J. and Giros, A. (2004) On the Possibility of Automatic Multisensor Image Registration. IEEE Transactions on Geoscience and Remote Sensing, 42, 2104-2120. https://doi.org/10.1109/TGRS.2004.835294

[40] Mercier, G., Moser, G. and Serpio, S.B. (2008) Conditional Copulas for Change Detection in Heterogeneous Remote Sensing Images. IEEE Transactions on Geoscience and Remote Sensing, 46, 1428-1441. https://doi.org/10.1109/TGRS.2008.916476

[41] Liu, Z., Mercier, G., Dezert, J. and Pan, Q. (2014) Change Detection in Heterogeneous Remote Sensing Images Based on Multidimensional Evidential Reasoning. IEEE Geoscience and Remote Sensing Letters, 11, 168-172. https://doi.org/10.1109/LGRS.2013.2250908

[42] Ban, Y., Ed. (2016) Multitemporal Remote Sensing: Methods and Applications (Remote Sensing and Digital Image Processing). Springer-Verlag, Berlin Heidelberg.

[43] NASA Earth Observatory (2015) Flooding in Mozambique. https://earthobservatory.nasa.gov/

[44] Biddlecome, T. (2000). Mozambique Floods from Landsat. NASA/Goddard Space Flight Center Scientific Visualization Studio. https://svs.gsfc.nasa.gov/cgi-bin/search.cgi?contentType=all

[45] Allen, J. and Simmon, R. (2013) Close-Up of Flooding in Mozambique. NASA Earth Observatory. http://earthobservatory.nasa.gov/

[46] Reliefweb (2013) Flood Waters over Chokwe, Guika, Bilene, and Xai-Xai Districts, Gaza Province, Mozambique (as of 25 Jan. 2013).

http://reliefweb.int/map/mozambique/flood-waters-over-chokwe-guika-bilene-andxai-xai-districts-gaza-province-mozambique

[47] TerraDaily (2013) Mozambique Floods Kill 36, Displace Tens of Thousands. http://www.terradaily.com/reports/Mozambique_floods_kill_36_displace_tens_of_t housands_999.html

[48] Merem, E.C., Wesley, J., Isokpehi, P., Nwagboso, E., Fageir, S., Nichols, S., Crisler1, M., Sheng-e, M., Romorno, C. and Hirse, G. (2016) Assessing the Vulnerability of the US Pacific North West Region to Tsunami Hazards. American Journal of Environmental Engineering, 6, 1-19.

[49] Country Meters (2017) Info/Zimbabwe/Malawi and Mozambique Populations. http://www.countrymeters.info/en/Zimbabwe

[50] GeoNames (2016) Mozambique-Largest Cities. http://www.geonames.org/MZ/largest-cities-in-mozambique.html

[51] GeoNames (2016) Malawi-Largest Cities. http://www.geonames.org/MW/largest-cities-in-malawi.html 
[52] GeoNames (2016) Zimbabwe-Largest Cities. http://www.geonames.org/ZW/largest-cities-in-zimbabwe.html

[53] Chemonics International Inc. (2017) Adapting to Climate Change in Mozambique's Coastal Cities.

http://www.chemonics.com/OurWork/OurProjects/Pages/Mozambique-Coastal-Cit y-Adaptation-Project.aspx

[54] Gerston, L., Quintela, C. and Quinn, C. (2017) Mozambique Cities Adapt to Climate Change One Tree and One Text Message at a Time. Chemonics International Inc., 17-18.

http://www.chemonics.com/OurWork/OurProjects/Documents/2015\%20-Frontline s\%20Climate\%20Issue\%20-\%20CCAP.pdf

[55] Irin (2009) Coastal Populations at Risk as Climate Changes. IRIN, Nairobi, Kenya. http://www.irinnews.org/feature/2009/05/20

Submit or recommend next manuscript to SCIRP and we will provide best service for you:

Accepting pre-submission inquiries through Email, Facebook, LinkedIn, Twitter, etc. A wide selection of journals (inclusive of 9 subjects, more than 200 journals)

Providing 24-hour high-quality service

User-friendly online submission system

Fair and swift peer-review system

Efficient typesetting and proofreading procedure

Display of the result of downloads and visits, as well as the number of cited articles Maximum dissemination of your research work

Submit your manuscript at: http://papersubmission.scirp.org/

Or contact ajcc@scirp.org 